\title{
Single Nucleotide Polymorphisms of Candidate Genes Related to Egg Production Traits in Vietnamese Indigenous Chickens
}

\section{-Author(s)}

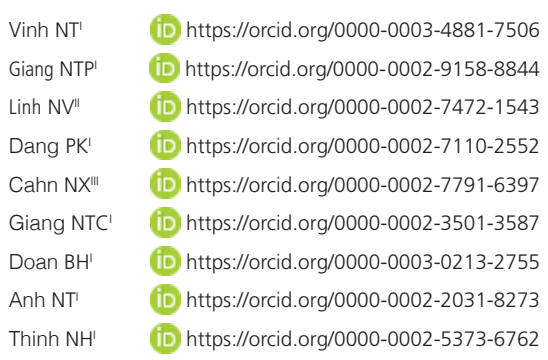

Animal Science Faculty, Viet nam National University of Agriculture.

Vietnam Academy of Science and Technology, Hanoi - Viet nam.

III Biotechnology Faculty, Viet nam National University of Agriculture.

\section{-Mail Address}

Corresponding author e-mail address Thinh Nguyen Hoang

Faculty of Animal Science, Vietnam National University of Agriculture, Trau Quy, Gia

Lam, Ha noi, Viet Nam.

Phone: +84 968643535

Email: nhthinh@vnua.edu.vn

\section{- Keywords}

Polymorphisms, GH gene, PRLR gene, PLR gene, Vietnamese indigenous chickens.

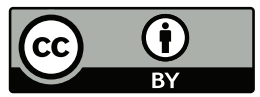

Submitted: 06/April/2020

Approved: 09/February/2021

\section{ABSTRACT}

The objective of this work was to detect single nucleotide polymorphisms (SNPS) in two candidate genes known to relate with reproductive traits in Vietnamese chicken. Two indigenous breeds Ri and Mia chickens were used for genotyping 4 SNPs namely intron 1 of growth hormon gene $(\mathrm{GH})$, exon 5 of prolactin receptor gene (PRLR5), a 24 bp nucleotide sequence insertion-deletion at situation -358 in 5'untranslated region of prolatin gene (PRL24); and at site C2404T of prolactin gene (PRL2402). It was shown that the SNP sites of these candidate genes were identified in two local breeds. Three genotypes of each loci were found (AA, AB and BB for $G H$; II, ID and DD for $24 \mathrm{bp}$ indel of PRL and CC, CT and TT for PRL2402), except only genotypes of $A A$ and $B B$ of PRLR5 were detected (no heterozygous genotype of $A B)$. The frequencies of the desired genotypes of $A A(G H), B B(P R L R 5)$, II (PRL24) and CC (PRL2402) were low in both indigenous Ri and Mia chickens. Based on this study it could be suggested that the study on association between these loci with egg production traits and the selection to increase the desired genotype frequency in poputions are necessary to improve egg production of Ri and Mia chickens.

\section{INTRODUCTION}

For many developing countries, indigenous chicken breeds play a key role in poultry production system. They make up from 55\% to $70 \%$ of the country's total poultry production (Hanh et al., 2007; Desvaux et al., 2008; Phuong et al., 2015). Vietnam is endowed with a variety of indigenous chicken breeds which not only contribute tangible benefits as meat and eggs, but also intangible benefits as gamecocks, savings, cultural, genetic diversity conservation. Meat and eggs from indigenous chickens are always preferred by consumers who are willing to pay a higher price as compared to industrial ones. Moreover, the indigenous chickens have unique combinations of adaptive phenotypes and genotypes that respond to the local environment condition and climate change in which they have developed and evolved. They have obtained important traits such as high adaptability of heat shock and disease resistance and consistence with poor quality feeds and cultural practices, and are attributed essentially for contributing to the sustainable development production in local production systems. However, with egg production the yield is only 55-78 eggs per hen annualy; the egg weight from $35 \mathrm{~g}$ to $40 \mathrm{~g}$; the local chickens begin laying at 22 weeks; they take more time to broody and rear their chicks. With these characteristics, the amount of products from indigenous chicken raising does not meet the needs of consumers and the indigenous diversity is increasingly leading to loss (FAO, 2007).

To improve egg production of indigenous breeds, many methods have been implemented such as selective breeding, enhancing feed 
Vinh NT, Giang NTP, Linh NV, Dang PK, Cahn NX, Giang NTC, Doan BH, Anh NT, Thinh NH
Single Nucleotide Polymorphisms of Candidate Genes Related to Egg Production Traits in Vietnamese Indigenous Chickens quality; housing; or veterinary support services (Dat et al.,2005) to enhance growth and reproduction of native chicken. However, the previous selection method is primarily based on the appearance characteristics so the selection's efficiency could be low.

Several candidate genes are related to reproductive traits, reducing the broody days and broody frequency of native breeds (Jiang et al., 2005; Cui et al., 2006; Bhattacharya et al., 2011). Among these genes prolatin $(\mathrm{PRL})$, prolactin receptor (PRLR) and growth hormone $(\mathrm{GH})$ genes have been widely studied and have significantly improved egg production and reduced broody behaviour (Cui et al., 2006; Rashidi et al., 2012; Stephen et al., 2000; Zhang et al., 2007; ). GH gene is highly polymorphic, more than 30 polymorphisms have been identified in chickens. A polymorphism in intron 1 related with egg yield, particularly, egg yeild of the individuals carrying haplotype A1/A1 was 15\% higher than others (Feng et al., 1997; Kuhnlein et al., 1997; Stephen et al., 2000; Zhang et al., 2007). Prolactin is a hormone best known for it's role in essential regulator of mammary development, which act to variety of hormones during sexual maturity and pregnancy (Yen et al., 1999; Clevenger et al., 2003). The higher concentration of circulating PRL occur with the increasing broody behavior. Besides, the ovarian follicle growth and egg laying performance were promoted by PRL (Zhang et al., 2015). The 24bp insertion/deletion (indel) mutation at the site of -358 in promotor region of PRL gene affected egg yeild in many native chickens (Jiang et al., 2005; Cui et al., 2006; Begli et al., 2010; Yousefi et al., 2012; Lotfi et al., 2013). Association of C2402T replacement mutation at $5^{\prime}$ flanking region of PRL gene with egg production trait was also found in chicken breeds in China, Iran and Ukraine (Cui et al., 2006; Liang et al., 2006; Rashidi et al., 2012; Bagheri et al., 2013; and Kulibaba, 2015). PRLR is a gene that synthesizes receptor polypeptide to receive the action of hormones, from that to start, control and maintain a range of functions of poultry reproduction such as hatching and broody behavious (Cui et al., 2006; Rashidi et al, 2012). Polymorphism in exon 5 of PRLR have a positive correlation with age and weight of hens at first egg laying (Rashidi et al., 2012).

Up to now, there are no studies to evaluate the association of $\mathrm{GH}$ and PRL and PRLR genes on egg production in two Vietnameses indigenous chicken: Ri and Mia chickens breeds. This study identified a single nucleotide polymorphism in intron 1 of $\mathrm{GH}$, exon 5 of PRLR, C2402T site and a 24bp nuclotide sequence indel of PRL genes in Ri and Mia chickens. This will be the initial scientific basis for further research to improve the egg yield of these two breeds.

\section{MATERIALS AND METHODS}

\section{Animals and sample collection}

This study was conducted on two populations of female native chicken breeds, namely Ri and Mia. Two breeds were raised in households of Son Tay District level town (lies $35 \mathrm{~km}$ west of the capital Hanoi) and National Institute of Animal Science, Vietnam.

The animals used must represent each breed to ensure the individual has no close relatives. To identify the polymorphism of intron 1 of $\mathrm{GH}$ and exon 5 of PRLR gene and C2402T and 24bp indel of PRL gene, a total of 72 Ri chickens and 114 Mia chickens were used in this study.

Individual blood samples were taken from the vein of chicken wing; and collected immediately in anticoagulant tubes (EDTA treated). The collected individual blood samples were transferred to the laboratory and stored at $-20^{\circ} \mathrm{C}$ for futher experiment.

\section{Genomic DNA extraction, PCR amplification reaction and genotyping identification methods}

Genomic DNA from blood samples were extracted using the procedure dicribed by Sambook et al. (1998) who improved some steps to suit the laboratory conditions. Spectrophotometer and agarose gel electrophoresis methods were used to check the quality and quantity of the extracted DNA. Genomic DNA samples had adjusted to final concentration of $50 \mathrm{ng} / \mu \mathrm{l}$ by using TE buffer.

Four pair of primers provided by Feng et al. (1997); Rashidi et al. (2012); Cui et al. (2006) were used to amplify the intron 1 of $\mathrm{GH}(\mathrm{GH})$, exon 5 of PRLR (PRLR5), C2402T site (PRL2402) and 24bp indel of PRL (PRL24) gene, respectively. The primer sequences for each marker loci are presented in Table 1. Primer pair GH was used to amplify the 900 bp fragment; primer pair PRL5 was used to amplified the $250 \mathrm{bp}$ fragment; primer pair PRL2402 was used to amplify 439 bp fragment; and primer pair PRL24 was used to amplified 154 or 130 bp fragments.

The PCR amplification reaction was performed final concentration 10ng of genomic DNA, $1.3 \mathrm{mM} \mathrm{MgCl}$, $0.15 \mathrm{mM}$ dNTPs, $0.3 \mu \mathrm{M}$ primers and $1.5 \mathrm{U}$ of Taq DNA polymerase (Thermo scientific) and $1 \times$ PCR buffer and de-ion water in a $25 \mu \mathrm{l}$ final volume. PCR reaction conditions of: (1) $\mathrm{GH}$ was following program: $95^{\circ} \mathrm{C}$ 
Vinh NT, Giang NTP, Linh NV, Dang PK, Cahn NX, Giang NTC, Doan BH, Anh NT, Thinh NH

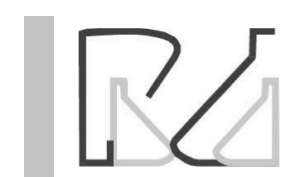

Table 1 - Primer pair sequences and Tm of candidate genes.

\begin{tabular}{|c|c|c|c|}
\hline Genes & Primer sequences $\left(5^{\prime}-3^{\prime}\right)$ & $\operatorname{Tm}\left({ }^{\circ} \mathrm{C}\right)$ & Product size (bp) \\
\hline GH & $\begin{array}{l}\text { F: ATCCCCAGGCAAACATCCTC } \\
\text { R: CCTCGACATCCAGCTCACAT }\end{array}$ & 60 & 900 \\
\hline PRLR5 & $\begin{array}{l}\text { F: TTGTCTGCTTTGATTCATTTCC } \\
\text { R: TGCATTTCATTCTTCCCTTTTT }\end{array}$ & 57 & 250 \\
\hline PRL24 & $\begin{array}{l}\text { F: TTTAATATTGGTGGGTGAAGAGACA } \\
\text { R: ATGCCACTGATCCTCGAAAACTC }\end{array}$ & 54 & 154 and 130 \\
\hline PRL2402 & $\begin{array}{l}\text { F: 5'-CTAAAGGACCTGGAAGAAGGG-3' } \\
\text { R: 5'-AACTTGTCGTAGGTGGGTCTG-3' }\end{array}$ & 52 & 439 \\
\hline
\end{tabular}

for $5 \mathrm{~min}$ followed by 28 cycles of $92^{\circ} \mathrm{C}$ for $30 \mathrm{sec}$, $60^{\circ} \mathrm{C}$ for $120 \mathrm{sec}, 72^{\circ} \mathrm{C}$ for $90 \mathrm{sec}$ and final extension of $72^{\circ} \mathrm{C}$ for $15 \mathrm{~min}$; (2) PRLR5 was at $94^{\circ} \mathrm{C}$ for $5 \mathrm{~min}$ following program: 30 cycles of $94^{\circ} \mathrm{C}$ for $60 \mathrm{sec}, 57^{\circ} \mathrm{C}$ for $60 \mathrm{sec}, 72^{\circ} \mathrm{C}$ for $60 \mathrm{sec}$ and final extension of $72^{\circ} \mathrm{C}$ for $15 \mathrm{~min}$; (3) PRL2402 was at $95^{\circ} \mathrm{C}$ for $2 \mathrm{~min}$, following program: 35 cycles of $94^{\circ} \mathrm{C}$ for $35 \mathrm{sec}, 52^{\circ} \mathrm{C}$ for $35 \mathrm{sec}, 72^{\circ} \mathrm{C}$ for $45 \mathrm{sec}$, with an ending step at $72^{\circ} \mathrm{C}$ for $15 \mathrm{~min}$.

For genotyping of GH, PRLR5 and PRL2402 genes, the PCR products were digested by Mspl, BamHI and Alul enzymes, respectively. $8 \mu \mathrm{L}$ of each amplified DNA fragments was digested at $37^{\circ} \mathrm{C}$ in 8 hours, in a final volume of $30 \mu \mathrm{L}$, containing $2 \mathrm{U}, 3 \mu \mathrm{L}$ of restriction buffer, and 19.6 $\mathrm{L}$ of $\mathrm{H}_{2} \mathrm{O}$, and appropriate restriction enzyme. The DNA fragments of digestive reaction were separated on 2,5\% agarose gel.

For genotyping of PRL24 containing the 24bp insertion or deletion, the PCR fragment was separated on 3\% agarose gel.

\section{Statistical analysis}

The distribution of genotypic frequencies and allelic frequencies of each SNP in two local chicken breeds were counted. Using a chi-squared test $\left(X^{2}\right)$ comparing the expected and observed genotype count to test Hardy-Weinberg equilibrium in two native chicken breeds. The data was analyzed using SAS software 9.1 (SAS 9.1., 2002)

\section{RESULTS AND DISCUSSION}

\section{PCR-RFLP analysis}

The electrophoretic profiles of the studied genes are shown in Figure 1. For intron 1 of GH gene, two alelles specific patterns were obtained after Msp/ digestion, allele A including $620 \mathrm{bp}$ and $280 \mathrm{bp}$ DNA fragments and three DNA fragments of $450 \mathrm{bp}, 280 \mathrm{bp}$ and 170 bp for allele $B$. Thus, this gene consequently result in three genotypes, AA (620 and $280 \mathrm{bp}), \mathrm{BB}(450,280$ and $170 \mathrm{bp})$ and $A B(620,450,280$ and $170 \mathrm{bp})$. The
Single Nucleotide Polymorphisms of Candidate Genes Related to Egg Production Traits in Vietnamese Indigenous Chickens

results show that the DNA banding patterns of GH was not respectively consistent with what was previously reported by Tanaka et al. (1992); Stephen et al. (2001); or Kazemi et al. (2018). When studying native chicken of Iran, Kazemi et al. (2018) show a PCR fragments of $776 \mathrm{bp}$; and using restriction reaction, with Mspl restriction enzyme, detected polymorphism in intron 1 of $\mathrm{GH}$ gene. The result obtained three kind of alleles of $A, B$ and $C$ and 6 different haplotype profiles (AA, BB, $C C, A B, A C$ and $B C$ ).
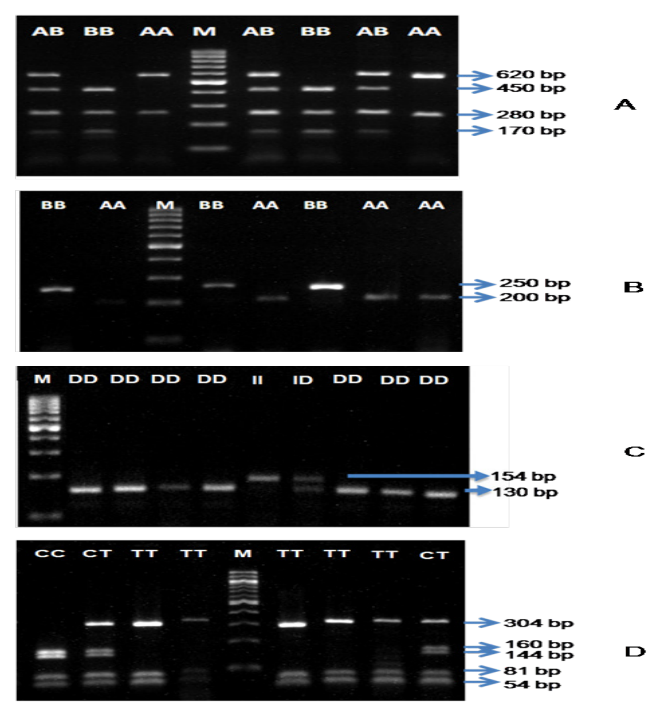

Figure 1 - PCR fragments of GH (A), exon 5 of PRLR (B), 24 bp Insertion-Deletetion PRLR (C) and C2402T PRLR (D) genes; genotypes were shown in image; M: DNA maker.

For exon 5 of PRLR, this stuty has obtained two allele $A$ and $B$; but just $A A$ genotypes and $B B$ genotypes were indentified in two native chicken breeds. Allele $A$ was an uncut 250bp fragment and allele B was 200 and 50 bp fragments. The heterozygous genotype $A B$ was absent in both $\mathrm{Ri}$ and Mia chickens. According to Rashidi et al. (2012), the fragment of PRLR5 was detected by digestion with $\mathrm{BamHI}$ restriction enzyme found in two bands of 195 and 55 bp. Including 195bp and 55 bp fragment for $A$ allele, while uncut fragment 250 bp for allele B because of the lack site for a BamHI restriction enzyme activity. However, Rashidi et al. (2012) also found there were no heterozygous females identified.

The genotyping of the $24 \mathrm{bp}$ insertion-deletion of PRL gene, three genotypes of II with 154 bp fragment (presence fragment $24 \mathrm{bp}$ ), DD with $130 \mathrm{bp}$ fragment (absence fragment $24 \mathrm{bp}$ ) and ID with 154 and 130 bp fragments were observed. The banding patterns of PRL24 were consistent to previously reports of (Rashidi et al., 2012; Sarvestani et al., 2012).

For PRLR at site C2402T, three genotypes of CC, TT and CT were obtained. Individuals with 4 fragments of 160, 144, 81 and 54 bp were designated as CC; 3 
Vinh NT, Giang NTP, Linh NV, Dang PK, Cahn NX, Giang NTC, Doan BH, Anh NT, Thinh NH

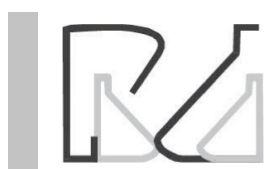

fragments of 304, 81 and 54 bp were designated as $T T$; and 5 fragments of 304, 160, 144, 81 and 54 were designated as CT. This result is consistent to previously results which was repored by Cui et al., (2005) and Sarvestani et al., (2012).

\section{Frequencies distribution}

The distribution of genotypic frequencies and allelic frequencies of each SNP in the two local chicken breeds tested are presented in Table 2 and 3.

The distribution of alleles and genotypes frequencies of all SNP tended to be the same in both Ri and Mia chikens. Frequencies of expected genotypes for egg production were lower as compared to others. Particularly, in Ri chicken, the frequency of AA (GH gene), BB (PRLR), II (PRL24) and CC (RPL2402) was $0.03 ; 0.01 ; 0.07$ and 0.06 , respectively. In Mia chiken, the frequency of these alleles was $0.02 ; 0.03 ; 0.07$ and 0.09 , respectively. There was no heterozygous genotype $A B$ of RPLR5 detected in both studied populations. The major reason for this is because the PRLR5 gene is located on the $Z$ chromosome, so in this situation there were no heterozygous females (Rashidi et al., 2012). In Ri Chicken, the genotype frequency distributions at every locus were all in Hardy-Weinberg equilibrium ( $(p>0.05)$, except for PRLR5 gene $(p<0.05)$. In Mia chicken, the genotype and allele frequency in intron 1 of GH gene were distributions in HardyWeinberg equilibrium ( $p>0.05)$ but the chi-squared test for PRLR5, PRL24 and PRL2402 genes deviated from Hardy-Weinberg equilibrium $(p<0.05)$.

For the traits of interest in production animal, the findings of QTLs, genes, SNPs responsible for genetic variation play an important role in genome selection and genomic analysis and animal breeeding (Rothschild

\section{Single Nucleotide Polymorphisms of Candidate Genes Related to Egg Production Traits in Vietnamese Indigenous Chickens}

\& Soller, 1997). In this study, some SNPs of candidate genes have previously been known to improve egg yield in several native chicken breeds and were applied in Ri and Mia Vietnamese native chickens for later use in selection and breeding.

The evaluation of genotypic and allelic frequency have been considered as an important factor for animal breeding and animal selection. Following, the next step in animal selection, is to evaluate the effect of these genotypes to interest phenotype traits which would help to select desirable individuals, with interest in genotype and phenotype traits. Under our study, the alleles associate with egg production had low frequencies in the Ri and Mia chicken population.

Previously, polymorphism of SNPs at intron 1 of Growth Hormone gene and its association with egg production traits was implemented. However, in our study in indigenous Ri and Mia chicken the result was different, with the PCR fragment of $900 \mathrm{bp}$, two alleles ( $A$ allele, $B$ allele) and three haplotypes (AA, AB, BB) were found. The frequencies of $A A$ genotype in Ri chicken population and Mia chicken population were 0.03 and 0.02 , respectively.

Cui et al. (2006) found the distribution of expected allele I (PRL24) and C (PRL2402) appears quite differently in Chinese chicken breeds: 0.02 and 0.02 (Taihe Silkies local chicken), 0.05 and 0.05 (Yangshan local chicken), 0.17 and 0.42 (Nongdahe local chicken), 0.22 and 0.35 (White Rock exotic chicken); 1.00 and 1.00 (White Leghorn exotic chicken). Arcorrding Cui et al. (2006), exotic chicken (White Leghorn chicken) breed can produce around 320 eggs per year because they do not present broodiness; two Chinese native Taihe Silkies and Yangshan chicken have strong incubation and lay almost 90 eggs and less than 70 eggs per

Table 2 - Distribution of genotypic and allelic frequencies of candidate genes of Ri chickens breed.

\begin{tabular}{|c|c|c|c|c|c|c|c|c|}
\hline \multirow{2}{*}{ Breeds } & \multirow{2}{*}{ Number of hens } & \multicolumn{2}{|c|}{ Allelic frequencies } & \multicolumn{3}{|c|}{ Genotypic frequencies } & \multirow[t]{2}{*}{$X^{2}(5.99)$} & \multirow[t]{2}{*}{$p$ value } \\
\hline & & Allele 1 & Allele 2 & 11 & 12 & 22 & & \\
\hline $\mathrm{GH}$ & 72 & A: 0.24 & B: 0.76 & $0.03(2)$ & $0.43(31)$ & $0.54(39)$ & 2.06 & 0.36 \\
\hline PRLR5 & 72 & A: 0.99 & B: 0.01 & $0.99(71)$ & 0 & $0.01(1)$ & 71.96 & $<0.01$ \\
\hline PRL24 & 59 & I: 0.19 & D: 0.81 & $0.07(4)$ & $0.25(15)$ & $0.68(40)$ & 1.80 & 0.41 \\
\hline PRL2402 & 59 & C: 0.22 & T: 0.78 & $0.09(5)$ & $0.27(16)$ & $0.64(38)$ & 2.36 & 0.31 \\
\hline
\end{tabular}

Note: Figures in brackets are the number of genotypes. $X^{2}=$ chi-square test.

Table 3 - Distribution of genotypic and allelic frequencies of candidate genes of Mia chickens breed.

\begin{tabular}{|c|c|c|c|c|c|c|c|c|}
\hline \multirow{2}{*}{ Breeds } & \multirow{2}{*}{ Number of hens } & \multicolumn{2}{|c|}{ Allelic frequencies } & \multicolumn{3}{|c|}{ Genotypic frequencies } & \multirow[t]{2}{*}{$X^{2}(5.99)$} & \multirow[t]{2}{*}{$p$ value } \\
\hline & & Allele 1 & Allele 2 & 11 & 12 & 22 & & \\
\hline $\mathrm{GH}$ & 114 & A: 0.18 & B: 0.82 & $0.02(2)$ & $0.33(38)$ & $0.65(74)$ & 1.09 & 0.58 \\
\hline PRLR5 & 114 & A: 0.97 & B: 0.03 & $0.97(111)$ & 0 & $0.03(3)$ & 78.95 & $<0.01$ \\
\hline PRL24 & 45 & I: 0.12 & D: 0.88 & $0.07(3)$ & $0.11(5)$ & $0.82(37)$ & 10.43 & $<0.01$ \\
\hline PRL2402 & 45 & $C: 0.11$ & T: 0.89 & $0.07(3)$ & $0.09(4)$ & $0.84(38)$ & 14.08 & $<0.01$ \\
\hline
\end{tabular}

Note: Figures in brackets are the number of genotypes. $\mathrm{X}^{2}=$ chi-square test. 
Vinh NT, Giang NTP, Linh NV, Dang PK, Cahn NX, Giang NTC, Doan BH, Anh NT, Thinh NH

year, respectively. The local chicken line (Nongdahe chicken), which was produced by China Agricultural University, lays 190 eggs per year. Frequency of allele I was found low in Ukrainian meat-line chicken (0.14) and high in egg-line chicken (0.73) (Kulibaba et al., 2012). When study in Fars native chickens (a high frequency of broodiness, producing 20-70 eggs during each laying period - 8 months) of Iran, Sarvestani et al. (2012) show two alleles were found for the SNP of C-2402T with frequency of 0.34 for $T$ and 0.66 for $C$. The 24-bp indel at the site -358 in promoter region of prolactin gene was shown to be polymorph with the observed genotypic frequency of 0.42 in II, 0.45 in ID and 0.13 in DD.

For some indigenous chicken breeds in Vietnam, Nguyen et al. (2018) found no individuals with homozygous genotype II (PRL24) and CC (PRL2402) was found in Lien Minh native chicken breed, with relatively low egg yield. Vu and Ngu (2016) observed low frequency (0.03) of CC (PRL2402) in native Noi chicken.

Study of Rashidi et al. (2012) with polymorphism exon 5 of PRLR of Iran indigenous chicken show there were no heterozygous females and the distribution of BB genotype was lower (0.28) than AA genotype (0.72).

Under the present study, the expected genotype frequencies of candidate genes in indigenous Ri and Mia chickens were low compared to other genotypes. This is entirely consistent with the egg production characteristics of indigenous chickens. Therefore, breeding programs need to be done to select chickens carrying the desired genotypes for enhancing egg production of indigenous chickens.

\section{CONCLUSION}

In conclusion, 4 SNPs of the GH, PRLR and genes were identified in both indigenous $\mathrm{Ri}$ and Mia chickens. Low frequencies of expected genotypes of $A A(G H), B B$ (PRLR5), II (PRL24) and CC (PRL2402) was observed in both breeds. These loci should be used for purpose of futher studies on the realtionship between genotype or allele with egg reproduction traits in $\mathrm{Ri}$ and $\mathrm{Mia}$ chickens.

\section{ACKNOWLEDGMENTS}

The authors would like to thank the manager of Vietnam National Institute of Animal Science for providing the chicken breeds.

\section{Single Nucleotide Polymorphisms of Candidate Genes Related to Egg Production Traits in Vietnamese Indigenous Chickens}

This study was carried out under the support by T2018 - $03-16$ TD project of Vietnam National University of Agriculture.

\section{CONFLICT OF INTEREST}

We declare that there is no conflict regarding the results discussed in the paper.

\section{REFERENCES}

Bagheri SAS, Niazi A, Zamiri MJ, Dadpasand T.M. Polymorphisms of prolactin gene in a native chicken population and its association with egg production. Iranian Journal of Veterinary Research 2013;14(2):113119.

Begli HE, Zerehdaran S, Hassani S, Abbasi MA, Ahmadi AK. Polymorphism in prolactin and PEPCK-C genes and its association with economic traits in native fowl of Yazd province. Iranian Journal Biotechnology 2010;8:172-177.

Bhattacharya TK, Chatterjee RN, Sharma RP, Niranjan M, Rajkumar U. Associations between novel polymorphisms at the $5^{\prime}$-UTR region of the Prolactin gene and egg production and quality in chickens. Theriogenology 2011;75:655-661.

Dat NH, Hung VT, Tung HX. Research to selectively improve the yield of yellow Ri chicken [scientific report of 2005]. Hanoi: Vietnam National Institute of Animal Husbandry; 2005. p.235-.239

Desvaux S, Vu DT, Phan DT, Pham TTH. A general review and a description of the poultry production in Vietnam. Hanoi: Agricultural Publishing House; 2008.

Clevenger CV, Furth PA, Hankinson SE, Schuler LA. The role of prolactin in mammary carcinoma. Endocrine. Reviews 2003;24(1):1-27.

Cui JX, Du HL, Liang Y, Deng XM, Li N, Zhang XQ. Association of polymorphisms in the promoter region of chicken prolactin with egg production. Poultry Science 2006;85:26-31.

FAO. People and animals. Traditional livestock keepers: guardians of domestic animal diversity. Specific features of raising livestock in humid tropical areas. Roma; 2007.

Feng XP, Kuhnlein U, Aggrey SE, Gavora JS, Zadworny D. Trait Association of genetic markers in the growth hormone and the growth hormone receptor gene in a white leghorn strain. Poultry Science 1997;76:17701775.

Hanh PTH, Burgos S, Roland HD. The poultry sector in Vietnam: prospects for smallholder producers in the aftermath of the HPAI crisis. Pro-Poor Livestock Policy Initiative (PPLPI) [research Report]. Roma: Food and Agriculture Organization of the United Nations; 2007.

Jiang RS, Xu GY, Zhang XQ, Yang N. Association of polymorphisms for prolactin and receptor genes with broody traits in chickens. Poultry Science 2005:84:839-845.

Kazemi H, Rezaei M, Hafezian H, Mianji GR, Najafi M. Genetic Analysis of SNPs in GH, GHR, IGF-I and IGFBPII genes and their association with some productive and reproductive traits in native breeder hens. Gene Technology 2018;7(1):145.

Kuhnlein U, Ni L, Weigend S, Gavora JS, Fairfull W, Zadworny D. DNA polymorphisms in the chicken growth hormonegene:response to selection for disease resistance and association with egg production. Animal Genetics 1997;28:116-123. 
Vinh NT, Giang NTP, Linh NV, Dang PK, Cahn NX, Giang NTC, Doan BH, Anh NT, Thinh NH

Kulibaba RA. Polymorphism of growth hormone, growth hormone receptor, prolactin and prolactin receptor genes in connection with egg production in Poltava Clay chicken. Agriculture Biology 2015;50(2):198207.

Liang Y, Cui J, Yang G, Leung FCC, Zhang X. Polymorphism of 5' flanking region of chicken prolactin gene. Domestic. Animal Endocrinology 2006;30(1):1-16

Lotfi E, Zerehdaran S, Ahani M, Dehnavi E. Genetic polymorphism in prolactin gene and its association with reproductive traits in Japanese quail. Poultry Science 2013;1(1):29-35.

Nguyen TTB, Duc NH, Thuy NTD. Association of prolactin gene polymorphism with egg production trait in Lien Minh chicken. Vietnam Journal Biotechnology 2018;16(2):259-266.

Rashidi H, Ghodrat RM, Ayoub F, Mohsen G. Association of Prolactin and Prolactin receptor gene polymorphisms with economic traits in breeder hens of indigenous chickens of Mazandaran province. Iranian Journal Biotechnology 2012;10(2):129-135.

Rothschild MF, Soller M. Candidate gene analysis to detect trait of economic importance in domestic livestock. Probe Newletter for Agriculture Genomic 1997;8:13-20.

Sambrook J, Fritsch EF, Maniatis T. Molecular cloning: a laboratory manual. New York: Cold Spring Harbor Laboratory Press; 1998.

Sarvestani AS, Niazi A, Zamiri J, Taromsari M. Polymorphisms of prolactin gene in a native chicken population and its association with egg production. Iranian Journal of Veterinary Research 2013;14(2):113119.
Single Nucleotide Polymorphisms of Candidate Genes

Related to Egg Production Traits in Vietnamese

Indigenous Chickens

SAS. Statistical Analysis Systems (2002) SAS. Version 9.1. Cary: SAS Institute Inc., Cary.; 2002.

Stephen CY, Zang $X$, Leung FC. Genomic growth hormone gene polymorphisms in native chinese chickens. Experimental Biology and Medicine 2001;226(5):458-462.

Tanaka M, Hosokawa Y, Watahiki M, Nakashima K. Structure of the chicken growth hormone-encoding gene and its promoter region. Gene 1992;112(2):235-239.

Vu CT, Ngu NT. Single nucleotide polymorphisms in candidate genes associated with egg production traits in native Noi chicken of Vietnam. Animal Environment Science 2016;6:162-169.

Yen SS, Jaffe RB. Reproductive endocrinology. $4^{\text {th }}$ ed. Philadelphia: Saunders; 1999

Yousefi S, Raoufi Z, Rasouli Z, Zerehdaran S. Invastigation of prolactin gene polymorphism in Japanese Quail. Animal Science Biotechnology 2012;45(1):289-292.

Zhang XL, Jiang X, Liu YP, Du HR, Zhu Q. Identification of Avai polymorphisms in the third intron of GH gene and their associations with abdominal fat in chickens. Poultry Science 2007;86:1079-1083.

Zhang D, Xu Z, He J, Ji C, Zhang Y, Zhang X. Polymorphisms in the 5 '-flanking regions of the GH, PRL, and Pit-1 genes with Muscovy duck egg production. Journal of Animal Science 2015;93(1):28-34 